\title{
(RE)EXISTÊNCIAS E O DEVIR REVOLUCIONÁRIO NA LITERATURA NEGRO-FEMININA
}

Ana Rita Santiago*

RESUMO: A produção literária de mulheres negras brasileiras apresenta, frequentemente, provocações e sinalizações de uma gramática literária atravessada por temas e propósitos que, a um só tempo, se ancoram entre sonhos por transformações e reinvenções de (re)existências, histórias e caminhos. Neste sentido, este texto aponta suas dicções literárias como práticas discursivas que transitam entre o devir revolucionário, elucidado por Gilles Deleuze (1990), e as travessias e pontes do (re)existir. Diante disso, este artigo faz leituras descritivo-interpretativas, pautada em poéticas e memórias de (re)existências e em algumas postulações do devir revolucionário, de algumas de suas tessituras poéticas.

PALAVRAS-CHAVE: Autoras negras; Devir revolucionário; (Re)existências.

\section{Algumas palavras iniciais}

\section{Ritos}

Do meu ventre nascem apenas as letras inúteis

E uns poemas que aprisiono ao pé da mesa.

Em cada palavra

Cantada

Despejo um óvulo macio

prenhe da luz

E de gritos.

\footnotetext{
* Doutora em Letras e Linguística pela Universidade Federal da Bahia (Ufba). Professora adjunta IV da Universidade Federal do Recôncavo da Bahia (UFRB). Membro permanente do corpo docente do Programa de PósGraduação em Crítica Cultural da Universidade do Estado da Bahia (Uneb), Departamento de educação, Campus II.
} 
Os filhos todos que não tive os sonhados, os esquecidos ou roubados, escorrem, líquido grosso entre minhas pernas numa ciranda dolorosa, e inextricável, Depois me torno, de novo, $\mathrm{O}$ invólucro brando da palavra: Límpida, Casta, Calma.

Volto a ter o útero de poeta. (NATÁLIA, 2011, p. 53) ${ }^{1}$

É preciso compreender a produção literária de autoras negras como um projeto integrante da literatura brasileira, através do qual se gestam palavras e narrativas (en) cantadas, comprometidas, não tão somente com a fruição, mas também com modos criativos e discursivos de mobilização de existências. Ao visitarmos produções literárias de autoras negras, tais como Maria Firmina do Reis, Auta de Souza, Antonieta de Barros, Carolina Maria de Jesus, Gilka Machado, Beatriz Nascimento, Nivalda Costa, Aline França, Geni Guimarães, Miriam Alves, Ana Maria Gonçalves, Conceição Evaristo, Alzira Rufino, Lia Vieira, dentre outras, denota-se, por um lado, quão ainda é importante apontar o cerceamento de vozes autorais de mulheres negras, bem como as práticas de invisibilidade de suas escrituras em circuitos culturais e literários. Significa, ainda, por outro, quanto urge acionar ovários e ventres que prenhes de palavras (en)cantadas, os quais despejem óvulos poéticos e narrativos, tais como cantados pela voz lírica de Ritos e forjem possibilidades de ecoar e ressoar vozes e narrativas negro-femininas.

Construir suas cartografias literárias possibilita, inclusive, reconhecer que, por muito tempo, a sua ausência na historiografia literária e em cenários culturais e acadêmicos 
deveu-se à falsa inexistência de sua autoria e ao apagamento de suas tessituras. Além disso, permite reconhecer que, embora alijadas de cenas literárias, autoras negras tatuam, em sua palavra literária, o indizível de si (nós) com formações discursivas de outros dizeres e narrativas de si (nós), por vezes, transgressoras, a cada tempo histórico e de suas existências individuais e coletivas. Como exercícios de resistências, em suas palavras literárias, por vezes, ecoam e transitam um eu que se quer nós.

Assenhoradas da palavra, autoras negras apropriam-se de fatos e informações, supostamente reais, hodiernos e fatídicos, tornando-os inefáveis e ficcionalizados, provocando ora fruição ora desassossegos poéticos e narrativos. Elas também inscrevem e (re)escrevem, em seus versos e prosas, fios e fiapos aleatórios e esparsos de recordações e lembranças, inventando memórias, igualmente, anacrônicas, pessoais e coletivas, esgarçando e diluindo fronteiras entre os eu (s) autoral, real e o ficcional, semelhante ao que apresenta Josefina Ludmer (2007), ao se referir às literaturas pós-autônomas.

Conhecer suas escrituras, nesse ínterim, significa reconhecê-las como sintaxes literárias, de aquilombamentos e ressignificações imaginárias e ficcionais, do vivido e do porvir, individual e coletivo, de ancestralidades, histórias e identidades negro-femininas, caminhos, sonhos, desejos, mas também desassossegos, dores e sofrimentos como se afigura em Ser poeta, de Jocélia Fonseca².

Ser poeta

É tomar um gole

De brasas acesas

E não beber água em seguida

Esse ventre há de parir

Tochas de palavras

E ações em chamas

Revertendo todo o processo

De um mundo caduco.

(FONSECA, 2012, p. 57)

${ }^{2}$ Jocélia Fonseca é poeta e membro do Coletivo Importuno Poético. 
Mediante as vicissitudes da existência e a sordidez e realidades tão insólitas e indizíveis, o exercício do (a) poeta assemelha-se a sorver um líquido quente, com sofreguidão e sem frescor ou alento como descreve a voz lírica de Ser poeta. Poetas negras têm arquitetado seus percursos e identidades autorais e, concomitantemente, provocado abalos e rupturas no cânone literário brasileiro, ocupado espaços significativos e forjado outras cenas literárias, como se propõe a voz poética de Ofício, de Cléa Barbosa 3 .

Fiz da poesia

Meu alimento diário

Minha bela veste

Meu par de saltos altos

Meu frisson de elegância.

A poesia tomou os meus pés

$\mathrm{E}$ fui para ruas, nas noites

Variados bichos soltos

Espantados

Fitando-me

Ensinando-me

O bem querer a esse ofício.

Fiz da poesia meu canto

A minha oração

É o eco de minhas palavras livres

Que vai de mim ao outro

Ah! Formosa dama poesia

Essencial é o teu cheiro

De absinto que me

Toma as narinas e faz-me

Bailar nas palavras soltas

Que possui minha alma

E eu entregue, já possuída

Até o último suspiro de mim

Refestelo-me

A importunar na embriaguez poética.

(BARBOSA, 2012, p. 31)

${ }^{3}$ Cléa Barbosa é poeta e membro do Coletivo Importuno Poético. 
Tal configuração impulsiona a pensar que se faz sempre necessário construir e, a um só tempo, reconhecer a tradição e crítica literárias consistentes de autoria feminina negra. Neste sentido, presumo que talvez nisso se configure alguma relevância de apontamentos e desassossegos sinalizados neste texto, já que apontam suas dicções literárias como práticas discursivas que transitam entre o devir revolucionário, elucidado por Gilles Deleuze (1990), e as travessias e pontes do (re)existir.

\section{Escrever para (re)existir}

A produção literária de mulheres negras brasileiras tem se configurado como uma gramática literária atravessada por temas que desfilam entre anseios por transformações e ressignificações de (re)existências e por fios históricos, imaginários e existenciais que tecem, descontínua e paulatinamente, suas tessituras literárias. Vale ressaltar, nessa perspectiva, a proposição do filósofo Giorgio Agamben (2009), no ensaio O que é contemporâneo que, ao caracterizar o poeta contemporâneo e sua função social, faz uma analogia entre ser contemporâneo e a moda, assegurando que a moda indica aquilo que "já é” e o "ainda não". Interpreto, de modo semelhante, as dicções literárias dessas escritoras: igualmente, aos modos de mobilizações que insurgem em suas existências, elas escrevem e publicam em ilhas urbanas (LUDMER, 2007) e fazem circular seus textos em diversos suportes tecnológicos e também no formato impresso com as condições e oportunidades que se apresentam ou forjam. Insurgentes e, às vezes, aquilombadas em coletivos, saraus, slam, iniciativas de empreendedorismo negros editoriais e culturais, elas giram suas assinaturas sintaxes poéticas e narrativas em construção. Nesse ínterim, elas “já são” autoras, mas “ainda não”, porque estão em permanente afirmação de suas marcas autorais e em busca de produção, edição, circulação e, também, reconhecimento e visibilidade de suas sintaxes literárias no cenário da literatura brasileira.

Suas tessituras, por vezes, não se enquadram, como alguns desejam e esperam, satisfatoriamente, em postulados de teorias e críticas literárias hegemônicas, tornando-as, por um lado, "inclassificáveis" mediante seus paradigmas e princípios, como explica a 
pesquisadora Maria Ester Maciel (2007), em Poéticas do Inclassificável, ao se referir às artes contemporâneas e aos seus modos de produção e veiculação. Desafiam, por outro, estudiosos (as) e críticos (as) a forjarem outras epistemes e chaves de leitura e interpretações que impliquem em saber de histórias, memórias, culturas, sagrado, (des)amores, solidão, ancestralidades, feminicídios, religiosidades, cosmovisões e tradições africanas e negrobrasileiras, africanidades, epistemicídios, filosofia ubuntu, intermuntu, ancestralidades, autoamor, feminimos e empoderamentos negros, genocídio, dentre outros elementos, referentes às populações negras e aos modos e condições de vida de mulheres negras. O poema Antirracismo, de Beatriz Nascimento, talvez, justifique tal necessidade.

Ninguém fará eu perder a ternura

Como se os quatro besouros

Geração da geração

Gestação da liberdade

Voo de garça, seguro

Ninguém me fará eu perder a doçura

Seiva de palma, plasma de coco

Pêndulo em extensão

Em extensivo mar-aberto

Cavala escamada em leito de areia

Ninguém me fará racista

Haste seca putrificada

Sem veias, sem sangue quente

Sem ritmo, de corpo, dura?

Jamais fará que em mim exista

Câncer tão dilacerado

(NASCIMENTO, 2015, p. 57)

A literatura negro-feminina tensiona, inclusive, outros discursos e representatividades de figuras negras, repertórios culturais africanos negro-brasileiros, Áfricas, histórias presentes em obras literárias brasileiras, bem como (in) escreve outros em que desenham as africanidades e o tornar-se negro (a) como um valor positivo, entrecruzados por exercícios de alteridade, emancipação e, principalmente, por escrituras de resistência. Assim, com a linguagem e a palavra criadora, escritoras negras ficcionalizam e cantam duras realidades 
vividas pelas populações negras e pobres espalhadas pelo Brasil, tal como se apresenta em Transgressão, de Beatriz Nascimento ${ }^{4}$.

\section{Transgressão}

(aula de micropolítica, Dona Martha. 01.09.1987)

Houve uma guerra no Rio

Para quem não soube um delírio

Produto de alucinação

Houve uma ação contra o morro

Armada e genocida

Que regeu aquelas colinas

De sangue de baixo acima

Ação de "Código Penal"

De impotência social

De esbirros e malfeitores

Arrogante e prepotente

Que atirou toda a gente

Num terror irrespondível

Houve gritos e choros

Que a cidade surda

Rapidamente esqueceu

E foi no Corcovado

No quilombo onde já aconteceu

Em algum tempo de história

Que na memória feneceu

Jamais foi contado

Pois lá era a mesma gente

E o país urgentemente

Apagou da mente

A verdade que passou

Mas não é passado é presente

Pra que repetição?

É necessário que abafes

O ruído das sirenes

Que perturba o ambiente

Dividindo os homens

Entre os bons e os maus

Entre nós e eles

${ }^{4}$ Beatriz Nascimento foi intelectual, pesquisadora, historiadora, poeta e ativista. Beatriz Nascimento (1942-1995) também foi roteirista do filme Ori (1989, $131 \mathrm{~min})$. 


\section{Entre vivos e mortos.}

(NASCIMENTO, 2015, p. 49)

Em tons narrativos e denunciativos, a voz poética expõe a ação sangrenta e dizimadora, em nome do cumprimento da lei, contra a gente que mora em um morro, onde já fora quilombo e lá já morara a mesma gente. Triste fim daqueles (as) que têm suas histórias marcadas por violências, terror e genocídios, acobertados pelo "Código Penal". Versos, produzidos há mais de 30 anos, mas se apresentam tão contemporâneos em sua temática e em consonância com tantos outros de autoras negras de diversos territórios brasileiros, semelhante a "Cirandeiros no mundo", de Elizandra de Souza5.

Bom dia, a educação vai mal

Transporte e saúde vão mal

Moradia também vai mal

E vocês dizem que o problema é reduzir a

Maioridade penal!

O silêncio também mata

Eu digo não à redução da maioridade penal

Adolescer não pode ser crime

As ruas não podem ser campo minado

Cuidado, cuidado, cuidado

Rouba a brisa, opinião pública

Genocida notícia

$\mathrm{Na}$ manchete menor mata

Menor rouba, menor, menor

$\mathrm{Na}$ tela apenas sequela

De um sistema falido

Combater a consequência

Mascarada fica a causa

Redução da maioridade penal

É dar tiros nos pés

Brincar de solução educacional

Prender o futuro no passado

Colocando curumins no sistema prisional

${ }^{5}$ Elizandra de Souza é poeta. Já participou de diversas antologias poéticas, dentre elas, Cadernos Negros e Ogum's Toques Negros. Publicou o livro Águas da cabaça (2012) (Poemas). 
Xangô, sabe os meninos, no relento,

Cirandeiros no mundo

Descalços na roda da vida

Queremos justiça e liberdade

E seguir os passos do vento...

(SOUZA, 2014, p. 84)

Vozes poéticas e narradoras se apresentam comprometidas, em um tom acusatório, com jogos discursivos que se erguem mediante injustiças, genocídio de populações negras, desigualdades sociais e raciais e o feminicídio negro ${ }^{6}$ como se apresenta nos pequenos poemas, de versos curtos, mas tão densos e incisivos em suas temáticas, respectivamente, de Lívia Natália e Louise Queiroz .

Maria não amava João.

Apenas idolatrava seus pés escuros.

Quando João morreu, assassinado pela PM,

Maria guardou todos os sapatos.

(NATÁLIA, 2015, p. 137)

A notícia saiu na primeira página

do jornal de segunda-feira:

um corpo atirou-se no rio Lete

e agonizou até a morte.

(QUEIROZ, 2016, p. 105)

Escrituras literárias de autoria negro-feminina ativam provocações relevantes, quiçá, transgressoras e conflitantes, além de promoverem releituras instigantes de construções literárias do Brasil, inventando e apontando modos e devires de (re)existir.

\footnotetext{
${ }^{6}$ Feminicídio negro significa morte de mulheres negras em razão do sexo, gênero e pertencimento etnicorracial. Indica a conduta de se ceifar a vida de uma mulher negra, em razão do gênero, sexo e cor (ou seja, em razão do fato de ser mulher negra), tendo como vítimas, em uma larga proporção, mulheres negras envolvidas em relacionamentos violentos, sendo normalmente ilícitos perpetrados por seus companheiros (as) (ou ex-companheiros) (as).

${ }^{7}$ Louise Queiroz participou da antologia poética Enegrescência (2016).
} 
Carolina Maria de Jesus $(1993)^{8}$, por exemplo, em Quarto de despejo - diário de uma favelada, sua obra mais conhecida, nacional e internacionalmente, narra - reinventando - a sua labuta cotidiana, como escritora, moradora de favela, catadora e vendedora de papel, em vista da sobrevivência, tal como o enfrentamento da fome e pobreza, reagindo às intempéries da vida em família e em sociedade. Em suas memórias literárias, aparecem seus dramas, revoltas e desencantos sem perder, às vezes, o encanto e a decisão pela vida e pela escrita.

...Eu escrevia peças e apresentava aos diretores de circos.

Eles respondia-me. - É pena você ser preta.

Esquecendo eles que eu adoro a minha pele negra, e o meu cabelo rústico.

Eu até acho o cabelo de negro mais iducado do que o cabelo de branco. Porque o cabelo de preto onde põe, fica. É obediente. E o cabelo de branco, é só dar um movimento na cabeça ele já sai do lugar. É indisciplinado. Se é que existe reincarnações, eu quero voltar sempre preta. (JESUS, 1993, p. 58)

Nessa sua primeira obra, Carolina Maria de Jesus auto-declara os motes e ensejos da sua escrita, ao longo de suas obras, tornando a fome e a miséria em palavras poéticas e ficcionais.

[...] Quando eu não tinha o que comer, em vez de xingar eu escrevia [...]. A favela é o quarto de despejo de uma cidade. Nós os pobres, somos os trastes velhos [...]. "[...] Escrevo a miséria e a vida infausta dos favelados [...].” (JESUS, 1993, p. 170-171; 173).

A fome, um dos temas caros a Carolina, não foi vivido por ela como um trabalho árduo da imaginação ou da prática (ou ausência) da solidariedade, caridade ou fraternidade, foi, infelizmente, uma amarga e triste companhia quase ao longo de toda a sua existência. Ela cria, assim, uma poética em que escancara os malefícios e má sorte daqueles (as) que

${ }^{8}$ Carolina Maria de Jesus (1915-1977) publicou as seguintes obras: Antologia Pessoal (obra póstuma), Quarto de despejo - Diário de uma favelada, Casa de Alvenaria, Provérbios, Pedacos da fome e Diário de Bitita. 
são acometidos (as) pela fome. A sua escrita foi um caminho necessário, quiçá, terapêutico e libertador para enfrentar as dificuldades para sobreviver, ajudando-lhe a suportar as intempéries, a fome, a miséria e a vida na favela, onde ela não gostava de morar nem das relações internas e externas que lá se estabeleciam.

15 de julho de 1955. Aniversário de minha filha Vera Eunice. Eu pretendia comprar um par de sapatos para ela. Mas o custo dos gêneros alimentícios nos impede a realização dos nossos desejos. Atualmente somos escravos do custo de vida. Eu achei um par de sapatos no lixo, lavei, remendei para ela calçar.

Eu não tinha um tostão para comprar pão. Então eu lavei 3 litros e deu-me pão. Fui receber dinheiro do papel. Recebi 65 cruzeiros. Comprei 20 de carne. 1 quilo de toucinho e 1 quilo de açúcar e seis cruzeiros de queijo. E o dinheiro acabou-se. [...] (JESUS, 1993, p. 9).

Em suas obras, são apresentadas memórias poéticas que se destacam pelo não distanciamento entre o real e o ficcional. Chamam a atenção por, a um só tempo, cantar, contar, ficcionalizando a si mesma, suas vivências e territorialidades e instigar práticas de interdições de sua voz autoral.

Fiquei alegre olhando o livro e disse: o que eu sempre invejei nos livros foi o nome do autor. E li o meu nome na capa do livro. "Carolina Maria de Jesus. Diário de uma favelada. Quarto de despejo". Fiquei emocionada. É preciso gostar de livros para sentir o que eu senti. (JESUS, 1993, p. 171)

Escrever para ela foi condição para existir e resistir: vivia porque escrevia. Assim, Carolina, ao escrever prosas, poesias provérbios, peças de teatro e letras de sambas, inscreveu-se em universos, discursos e lugares e, ao mesmo tempo, provocou deslocamentos da figura do (a) autor (a), desmobilizando conceitos como autoria, cânone, literatura e pondo, sob rasura, a função social da arte literária.

Eu era revoltada, não acreditava em ninguém. Odiava os políticos e os patrões, porque o meu sonho era escrever e o pobre não pode ter ideal nobre. Eu sabia que ia angariar inimigos, porque ninguém está habituado a esse tipo de literatura. Seja o que Deus quiser. Eu escrevi a realidade. (JESUS, 1993, p. 173) 
Tecer memórias sobre si, imbuídas de autoficcionalização de suas histórias, desejos, sabores e dissabores vividos foi, possivelmente, para Carolina, escrever também sobre mundos, outros (as) e realidades que lhe circundaram. Neste sentido, sua escrita poética é travestida de tantos outros eu (s), lugares e circunstâncias, marcada pela inquietude e angústia, advindas da dura realidade da fome, miséria e de suas consequências. Escrever para dizer de (nós) e, se necessário for, para se reinventar, longe de paradigmas, estigmas e estereótipos prevalentes na tradição literária brasileira. Escrever para (re)existir! Essa é uma das máximas que acompanham a construção da identidade autoral de Carolina Maria de Jesus e de outras mulheres negras escritoras.

Existir e Resistir são epítomes que desenham a sua escritura, uma vez que, através da escrita, mobilizam devires e modos de resistência tal como se apresenta a voz poética de "Mulher torturada", de Lia Vieira?.

Que prêmio receberão os carrascos

pela realização de sua carreira torpe?

A mim, cabe sofrer as consequências em martírio para salvar a minha ideologia.

Saciar através dele

a fome de igualdade e fraternidade no meio social a que pertenço.

NÃO SEI FAZER O JOGO.

A pressa dele em mim infringe dor

Dói mas psíquica que fisicamente.

Que prepotência em querer ser

Negando a razão que só a Deus pertence.

(VIEIRA, 2014, p. 134)

São, comumente, alaridos líricos e épicos que, propositivamente, sinalizam possibilidades de empoderamento negro e forjam, pela imaginação, caminhos de conquista de direitos civis e socioculturais, valorização de repertórios culturais negros e, por conseguinte,

${ }^{9}$ Lia Vieira é poeta e publicou os livros Eu mulher - mural poesias (1990); Chica da Silva - a mulher que inventou o mar (2011) (Infanto-juvenil); Só as mulheres sangram (2011) (Contos). Já participou de diversas antologias poéticas, dentre elas, Cadernos Negros e $c$ 
de emancipação, semelhante às prerrogativas do sujeito lírico de "Não vou mais cuidar", de Cristiane Sobral ${ }^{10}$.

Não vou mais cuidar do senhor

Agora quero um tempo para mim

Paquerar minhas carnes no espelho

Arreganhar os olhos com rímel

Sair

Não vou mais cuidar do senhor

Eu tenho outras coisas pra fazer

Liberta do exercício de cuidar de outrem

Talvez conheçam meu verdadeiro valor

Não vou mais cuidar do senhor

Quero tomar um banho gostoso

Esfregar a consciência

Sem temer qualquer indecência

Não vou mais cuidar do senhor

Abaixo o discurso maniqueísta

A ilusão não pode sair mais cara que o sonho

Prepare-se meu senhor

Antes de sair

Quero gozar

Desfrutar a cama imensa

Serei muito mais do que você pensa

Este é um lema para manter

Terei tempo para ser e não ser

Não vou mais cuidar do senhor

A vida é curta para não desfrutar o amor.

(SOBRAL, 2016, p. 38)

Escrever é, neste sentido, indubitavelmente, criar vozes que se/nos reescrevem e, concomitantemente, inscrevem-se/nos em novos lugares, discursos, imaginários, papeis sociais e vivências que demarcam práticas discursivas interseccionadas por lirismos, afirmações, desconstruções e múltiplos modos de existir. Além disso, se recolocam como se-

${ }^{10}$ Cristiane Sobral é atriz, escritora e já participou de várias antologias poéticas, dentre elas, Cadernos Negros. Publicou as seguintes obras: Uma boneca no lixo (1998) (Dramaturgia); Dra. Sida (2000) (Dramaturgia); Não vou mais lavar os pratos (2010) (poemas); Espelhos, miradouros, dialéticas da percepção (2011) (Contos); Só por hoje eu vou deixar meu cabelo em paz. (2014) (Poemas); e O tapete voador (2016) (Contos). 
nhoras que procuram e realizam seus desejos sexuais e reivindicam, como sujeitos de direitos, o gozo, o prazer e o amor. Reposicionam suas vozes e seus corpos como um permanente reinventar-se/nós como desfilam os versos de Fé, de Vania Melo ${ }^{11}$.
Saio de casa, caminho cada passo me celebra sou quem perdeu os medos poeta.
Não entendo chamar de meus Os passos que se dão sozinhos Ateus.

$$
\text { (MELO, 2018, p. 16) }
$$

Entre os múltiplos ditos e desditos que forjam, em seus percursos, algumas autoras negras também ousam assenhorar-se da arte da palavra para escrever de si (nós) como oportunidade para (des)dizer, pela linguagem poética, ditos sobre si, bem como modos de (re)existir, logo de instituir-se. É um exercício autoral que poderá, inclusive, operacionalizar discursos tidos como verdadeiros ou hegemônicos em probabilidades de reversões de olhares e recriações de si e reinvenções de outras (SANTIAGO, 2010), deslocando-se do território de personagens para autoras. Tal movimento, indubitavelmente, metamorfoseia não só o transcurso de suas vidas, mas também das trilhas literárias brasileiras. Migrar da leitura para a escrita, permanecendo leitoras de mundo, de si e do que lhe circunda, possivelmente, possibilita-lhes alçar outras percepções da vida, semelhante ao que se configura em Desquites, de Gonesa Gonçalves ${ }^{12}$.

\footnotetext{
"Meu facão cortou embaixo, a bananeira calu"

Já bebi das minhas lágrimas

e lambi sangue das minhas feridas

e você ria, ria

me pondo freios e brindando com o melhor vinho

e eu hoje,
}

\footnotetext{
11 Vânia Melo é autora do livro de poemas Sobre o breve voo das borboletas e suas esquinas (2018).

12 Gonesa Gonçalves participou da antologia poética Enegrescência (2016).
} 


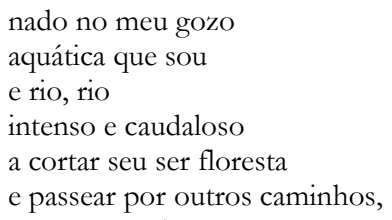

(GONÇALVES, 2016, p. 61)

Traçam-se outros caminhos, outras histórias e historiografias literárias e, ao mesmo tempo, trançam-se ficções para tear outros mundos e narrativas, abordando temas e questões prementes que lhes rodeiam, tais como sexualidade, sexismo, escrita, exclusão, racismo, violência, seja ela moral, física seja simbólica, aborto, estupro, crises, resistências, sonhos, labutas, solidão, decepções, genocídios, morte, (des)amores... Assim o que parece apenas ser fato e hodierno tornam-se narrativas e poéticas que se transfiguram e se ficcionalizam.

\section{O devir revolucionário em poéticas de resistência}

Em tempos de distopias e exceção, fracassos de grandes revoluções (macropolíticas), meta-narrativas, rupturas de epistemologias comunistas e socialistas, disseminação de discursos antidemocráticos e antirrevolucionários e apropriação histórica do fascismo e nazismo, presumo que se torne necessário se repensar em outros modos de lutas libertárias e revisitar o sentido de devir-revolucionário, apresentado por G. Deleuze (1990), e retomado, dentre outros, pelo filósofo Michel Onfray, ao discutir sobre materialiasmo hedonista (1999) e o devir revolucionário dos indivíduos (2001), em oposição aos ideais da revolução social.

Por esse devir, segundo Deleuze, torna-se possível construir práticas de enfrentamento de intolerâncias e respostas para expurgar a vergonha das atrocidades derivadas dos regimes fascistas e nazistas.

[...] estamos constantemente misturando duas coisas, o devir das revoluções na história e o devir revolucionário das pessoas. Não se trata das mesmas pessoas nos dois casos. A única chance dos homens está no devir- revolucionário, o único movimento capaz de esconjurar a vergonha ou responder ao intolerável. (DELEUZE, 1990 , p. 68) 
O devir-revolucionário, para Deleuze, sob a esteira do estatuto das "Máquinas de guerra",

[...] consiste em procurar o estatuto das "Máquinas de Guerra", que não se definiriam de forma alguma pela guerra, mas por uma certa maneira de ocupar, de preencher o espaço-tempo, ou de inventar novos espaços-tempos: os movimentos revolucionários (não analisamos suficientemente, por exemplo, como a OLP precisou inventar um espaço-tempo no mundo árabe) e também os movimentos artísticos são tais máquinas de guerra [...] (DELEUZE, 1990, p. 69)

A invenção de novos espaços-tempos, como exercício de resistência - devir-revolucionário -, viabiliza estratégias de se (re)ocupar e acreditar no mundo e em transformações, não mais, tão somente, pela esfera da macropolítica e da tomada do poder, mas também pelas revoluções cotidianas, notabilizadas por meio de atitudes e atos militantes e de rebeldia no hodierno (macrossocial). Nessa perspectiva, é preciso, de acordo com Deleuze,

[...] Acreditar no mundo é o que mais nos falta; perdemos o mundo; ele nos foi tomado. Acreditar no mundo é também suscitar acontecimentos, mesmo que pequenos, que escapem do controle, ou então fazer nascer novos espaços-tempos, mesmo de superfície e volume reduzidos [...] (DELEUZE, 1990, p. 70)

Um devir-revolucionário, nesse ínterim, não agencia ou prioriza, unicamente, a criação de estratégias de tomada de poder. É um devir que estabelece relações com outros devires e "revolucionários", a fim de se pensar em micropolíticas. Não há mais uma única linha que liga opressão - revolução - utopia. Há linhas, sem linearidades, que se destecem, descolam e trilham múltiplas travessias, tecendo várias pontes e caminhos inesperados ou organizados. Um devir-revolucionário acionam deslocamentos, atravessamentos de linhas e desvios e acontecimentos à procura de outros agenciamentos de vida que sejam revolucionários.

Ademais, o devir-revolucionário constitui-se como possíveis formas de forjar novos modos de luta, intervenções e mobilizações através do discurso criativo e outros modos de fazer política, tendo em vista ações libertárias no (do) presente. É uma prática existencial 
do presente que se reverbera em atitudes revolucionárias e libertárias que operam no aquie-agora e em experiências que buscam relações horizontais, confrontando e enfrentando múltiplas formas de segregações. É também uma prática de valorização do individual na coletividade e nas relações em oposição às diversas formas de dominação, autoritarismo e opressão, visando criar contínuas resistências e modos críticos e incisivos de insubmissão de seus corpos, vozes, histórias e caminhos.

O devir-revolucionário, nesses aspectos, pode ser um princípio epistêmico e chave de leitura, interpretação e crítica de tessituras literárias de autoras negras, porque, por vezes, elas se apresentam como escritas poéticas do cotidiano (microssocial) e de resistências. Em seus versos e prosas desfilam práticas de micropolítica, com o intuito de fortalecer discursos libertários e visibilizar esforços diários para sobreviver e resistir, tal como a voz poética de "Autobiografia" se apresenta.

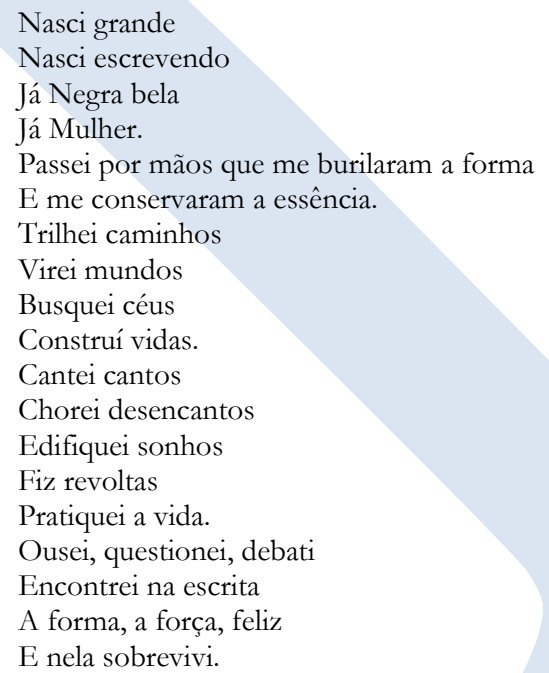

(VIEIRA, 2014, 137)

A micropolítica não é pequena política, ela pode ser maior que qualquer ato de revolução social. Não é inferior, ela pode mobilizar tanto quanto as grandes manifestações de ruas. Uma micropolítica é uma política menor: se faz por movimentos minoritários, se 
faz por linhas de fuga que desestabilizam o status quo, onde discursos e instâncias hegemônicas não alcançam. Quiçá, nesse limiar, inscreva-se um devir-revolucionário do eu ficcional de "Autobiografia".

Como poéticas de resistência no (do) cotidiano, a literatura negro-feminina tem inventando e valorizado ações cotidianas como sinalização de posicionamentos políticos da existência, tal como se desfigura nos versos de "Brejo", de Rita Santana ${ }^{13}$.

Angélicas acalentam durante melhor o dia o olhar

Sobre os meus pés de menina que sente o cheiro do brejo.

Há uma vizinha que enlouquecerá,

Há o nome tanto, filhos belos, casa decorada,

Prosperidade e segurança.

Há no quintal da casa um brejo,

Há caixas de ovos, cheirando a isopor branco,

Há o menu do futuro nas mãos da minha mãe,

Órfã nos dias dos nossos passos.

Haverá melancolias de tardes com as vizinhas da minha mãe.

A poesia me oferta remissão,

A facilidade das confissões,

O esconderijo dos pequenos furtos,

Mas, e a vida

Tenham paciência com os meus desatinos amarelos,

Tenham paciência com os meus desatinos vermelhos,

Paciência com minha inapetência pras paciências diárias.

Confesso meu pânico, a minha demência cega.

Sou poeta! Eis minha pena, meu punhal, meu álibi.

Minha balança.

(SANTANA, 2006, p. 37)

Tal poética de (re)existências e do cotidiano se apresenta como possibilidades inventivas de estar no mundo e também de fazer política para além de partidos e outras

${ }^{13}$ Rita Santana é autora dos seguintes livros Tratado das veias (Poemas), Tramela (Contos) e Alforrias (Poemas). 
organizações sociais e políticas hegemônicas, semelhante aos versos e trocadilhos e ironias de "Tribunal das Descarações", de Gabriela Ramos"14.

Sem presunção de inocência

Fichas sujas sem trânsito em julgado

Onde passeiam descarados réus

Com infinitos ministros

O Suspeito Tribunal da Fidelidade

$\mathrm{Na}$ iminência de quebrar sigilos (a) morais

Determina o segredo de injustiças amorosas

Resguarda Pragmatismos sexuais

Transcende a Formalismos sociais

Liberta Racionalismos conjugais.

(RAMOS, 2014, p. 93)

Mediante descasos políticos e judiciais, descumprimentos da justiça, corrupções, desesperanças e cansaços restam, parece, as artes e a ancestralidade para muitas mulheres negras! Se assim for, presumo que àquelas que são escritoras resta-lhes a arte da palavra! Cabe, pois, escrever para resistir e exercer micropoderes como acena M. Foucault, em $A$ microfísica do poder (1997).

Em meio a tantos dissabores, abandonos, racismo, dominação, misoginias e sexismo, desesperanças o devir-revolucionário da escrita, talvez, permita sobreviver e resistir. Em "135 docíveis”, de Cristiane Sobral, o sujeito lírico, como exercício de sua soberania e compromisso com a valorização e respeito de sua negritude, se apropria de algumas "verdades" para desmobilizá-las.

A sua consciência humana abraça a hipocrisia sacana que finge gostar dos meus cabelos crespos enquanto sugere um produto para baixar o meu volume liga o som vai escute os acordes expressão da minha cultura ouça no máximo

no topo

onde reinam os meus fios negros

${ }^{14}$ Gabriela Ramos é poeta e participou da antologia poética Ogum's Toques. 
hoje é 21 de novembro

minha consciência continua negra

[negra mais que ontem

negra]

Amanhã não será dia de branco.

Por uma humanidade mais humana.

(SOBRAL, 2016, p. 35)

Como ato de micropoder, o devir-revolucionário de autoras negras com o tom desses versos é, por vezes, motivação e razão para as suas sintaxes literárias. Com esse devir, pode-se dižr aos pequenos e grandes grupos, territórios, tempos e às pessoas sobre desassossegos, dores, angústias, mortes violentas, (des)encontros, sonhos, poesia, sofrimentos, ancestralidades, desalentos, utopias, decepções, memórias, (des)crenças, histórias, (des)afetos, solidariedade, desejos, dentre outros.

"Há situações nas quais a única saída para o homem é o devir-revolucionário", como declarou Deleuze (1990, p. 68). Há tempos e territórios de histórias individuais e coletivas em que a arte é uma saída ou ainda um ato de devir-revolucionário para o (a) artista. O devir-revolucionário, se figura como alternativa ao tempo presente em escritas de autoras negras: é preciso "levantar", como sugere o poema "Ainda assim me levanto", da escritora afro-americana Maia Angelou, e resistir em meio "a tantos não e a tantas marginalidades", conforme cantado, em "Alegria da cidade”, pelo músico e compositor Lazzo Matumbe.

A arte da escrita de autoras negras, desse modo, como prática do devir-revolucionário, torna-se uma saída para não só dizer de si (nós), mas também para reinventar modos de (re)existir e forjar alternativas de (re)encontros e estar no mundo. As singularidades, juntamente com o potencial criativo, que desfilam em suas poéticas e narrativas, associadas a uma multiplicidade de motes, temas, situações, inquietações e vivências, como mulheres negras, impulsionam uma escrita pulsante, movimentada por um agir micropolítico, mobilizando inovações e resistências que desembocam do eu-para-si para outros (as). Nesse sentido, versos e prosas aproximam-se de uma prática de um devir-revolucionário que “[...] permanece indiferente às questões de um futuro e de um passado da revolução; ele passa 
entre os dois. Todo devir é um bloco de coexistência”, como assegura Deleuze (1990, p. 63).

\title{
Algumas considerações (in)conclusivas
}

É preciso (re)existir! Utopias e distopias, opressões e revoluções se canibalizam, em tessituras literárias negro-femininas, provocando desconfortos, micropolíticas, descolamentos e esgarçamentos que desestabilizem ou, ao menos, desloquem possíveis ancoradouros da literatura brasileira, vislumbrem possibilidades existenciais, individuais e coletivas dentro e fora dos espaços poéticos e ficcionais e se criem outros territórios promissores no bojo da literatura brasileira. São, parece, na perspectiva de um devir-revolucionário, que autoras negras têm encenado o seu fazer literário insurgente e inventado travessias e pontes insubmissas para seguir em atravessamentos que se exibem em vicissitudes e idiossincrasias das existências. Assim mais um desafio se apresenta à crítica e a(o)s estudiosa(o)s de suas produções literárias: Compreender e problematizar mais as marcas do devir-revolucionário em suas poéticas de resistência e do cotidiano.

\section{(RE)EXISTENCES AND THE REVOLUTIONARY DEVIR IN BLACK-FEMININE LITERATURE}

\begin{abstract}
The literary production of black Brazilian women often presents provocations and signs of a literary grammar that is crossed by themes and purposes that, at one and the same time, anchor themselves between dreams through transformations and reinventions of (re)existences, histories and paths. In this sense, this text points to its literary dictions as discursive practices that pass between the revolutionary becoming, elucidated by Gilles Deleuze (1990), and the crossings and bridges of (re)exist. In the light of this, this article makes descriptive-interpretative readings, based on poetic and re-existent memories and on some postulates of the revolutionary becoming of some of its poetic writing.
\end{abstract}

KEY-WORDS: Black authors; Becoming revolutionary; (Re)existences

\section{REFERÊNCIAS}

BARBOSA, Cléa. Ofício. In: BARBOSA, CLÉA et al. Importuno poético. Salvador, 2006. 
DELEUZE, G.; NEGRI, Toni. O devir revolucionário e as criaçôes políticas. Entrevista de Gilles Deleuze e Toni Negri. Trad. João H. Costa Vargas. Novos Estudos CEBRAP. N. 28, outubro 1990. pp. 67-73.

FONSECA, Jocelia. Ser poeta. In: BARBOSA, CLÉA; FONSECA, Jocelia; OLIVEIRA, Lutigarde. Importuno poético. Salvador, 2006.

FOUCAULT, M. A microfísica do poder. Trad. Andréa Daher. Rio de Janeiro: Jorge Zahar, 1997.

GONÇALVES, Gonesa. Des-quites. In: ALVES, David; NUNES, Davi;

PSEUDOPOETA, Atmo; SOBRINHO, Cezar; SOBRINHO, Cristiane; David Alves, et ali. Enegrescência - coletânea poética. Salvador: Editora Ogum’s Toques Negros, 2016.

JESUS, Carolina Maria de Jesus. Quarto de despejo. Diário de uma favelada. 2. Ed. São Paulo: Ed. Ática, 1993.

LUDMER, Josefina. Literaturas pós-autônomas. Sopro - panfleto poético cultural.

Desterro, Janeiro, n. 20, 2010. Disponível em http:/ /www.culturaebarbarie.org/sopro/>. Acesso em 20.09.2018.

MACIEL, Maria Esther. Poéticas do inclassificável. Aletria. Belo Horizonte, jan-jun, vol. 15. Disponível em < http:www.letras.ufmg.brposlit $>$. Acesso em 15.09.2018. pp.155-162.

MELO, Vânia. Fé. In: Sobre o breve voo das borboletas e suas esquinas. Salvador: Organismo editora, 2018)

NASCIMENTO, Beatriz. Transgressão. In: GOMES, Bethania; Ratts, Alex (Org.). Todas (as) distâncias: poemas, aforismos e ensaios de Beatriz Nascimento. Salvador: Ed. Ogum's Toques Negros, 2015.

Antirracismo. In: GOMES, Bethania; Ratts, Alex (Org.). Todas (as) distâncias: poemas, aforismos e ensaios de Beatriz Nascimento. Salvador: Ed. Ogum's Toques Negros, 2015.

NATÁLIA, Lívia Natália. Ritos. In: Água Negra. Salvador: Banco Capital, 2011.

2015.

. Quadrilha. In: Correntezas e outros estudos marinhos. Salvador: Ed. Ogum's Toques,

ONFRAY, Michel. $A$ arte do prazer: por um materialismo hedonista. São Paulo: Marins Fontes, 1999. . A política do rebelde: tratado de resistência e insubmissão. Rio de Janeiro: Rocco, 2001

QUEIROZ, Louise. Notícia. In: ALVES, David et ali. Enegrescência - coletânea poética. Salvador: Editora Ogum's Toques Negros, 2016. 
SANTANA, Rita. Brejo. In: Tratado das veias. Poesia. Salvador: Secretaria da Cultura e Turismo; Fundação Cultural do Estado da Bahia; EGBA, 2006. . Vozes literárias de escritoras negras. Cruz das Almas/BA: EDUFRB, 2012.

SOBRAL, Cristiane. Não vou mais cuidar. In: ALVES, David et ali. Enegrescência - coletânea poética. Salvador: Editora Ogum’s Toques Negros, 2016.

. Cristiane. 135 docíveis. In: ALVES, David et ali. Enegrescência - coletânea poética. Salvador: Editora Ogum's Toques Negros, 2016.

SOUZA, Elizandra. Cirandeiros no mundo. In: ADÚN, Marcus Guellwaar et al. (Org.). Ogum's toques negros: coletânea poética. Salvador: Editora Ogum’s Toques, 2014.

VIEIRA, Lia. Autobiografia. In: ADÚN, Marcus Guellwaar et al. (Org.). Ogum's toques negros: coletânea poética. Salvador: Editora Ogum’s Toques, 2014.

Lia. Mulher Torturada. In: ADÚN, Marcus Guellwaar et al (Org.). Ogum's toques negros: coletânea poética. Salvador: Editora Ogum’s Toques, 2014.

Recebido em: 29/08/2018.

Aprovado em: 29/01/2019. 